Open Access

\title{
Integration of learning technologies into teaching within Fijian Polytechnic Institutions
}

\author{
Shalendra Kumar and Ben Kei Daniel ${ }^{*}$
}

\author{
* Correspondence: \\ ben.daniel@otago.ac.nz \\ University of Otago, Dunedin, \\ Otago, New Zealand
}

\begin{abstract}
In the $21^{\text {st }}$ century, learning technologies have increasingly become pervasive within various forms of learning environments. Institutions of higher education are increasingly turning to these technologies to resource and support their teaching and learning environments under distributed circumstances, face-to-face or blended. Recently, the Fijian Ministry of Education systematically introduced learning technologies into Fiji's technical colleges to support teaching and learning. However, prior to the widespread deployment of these technologies, little information was available on educators' perception of the value of these technologies, and the extent to which this could influence adoption. The purpose of this study was to gain a better understanding of lecturers' perceptions of the value of learning technologies and factors likely to influence their decisions to adopt and integrate these technologies into teaching as well as challenges they are likely to face. A survey was administered to fifty five self-selected lecturers involved in teaching within three Polytechnics in Fiji. Although overall findings suggested that lecturers strongly valued the contribution of learning technologies in enhancing student learning, a number of factors likely to influence the rapid adoption of these technologies were identified. These included attitude towards technology and perceived usefulness of technology in teaching, the institutional cultural environment, as well as resources available to support uptake. This research contributes to the growing significance of individual, contextual and cultural influences in the adoption of learning technologies into teaching.
\end{abstract}

Keywords: Learning technologies, Attitude, Perceived usefulness, Ease of use, Compatibility, Perceived behavioural control, Self-efficacy, Behavioural intention, Subjective norms

\section{Introduction}

Learning technologies refer to as e-Learning, refers to a suit of technologies to support teaching or learning. These also include technological platforms that support virtual learning environments (VLEs) (Sife, Lwoga, \& Sanga, 2007). Sife, et. al, (2007) identified different types of educational technologies, ranging from those that are used as supplementary learning support tools and environments, those that support classroom (PowerPoint), and others that are used as hybrid or blended, supporting face-to-face and fully online instruction (Arabasz \& Baker, 2003). In the last few decades there has

(c) 2016 The Author(s). Open Access This article is distributed under the terms of the Creative Commons Attribution 4.0 International License (http://creativecommons.org/licenses/by/4.0/), which permits unrestricted use, distribution, and reproduction in any medium, provided you give appropriate credit to the original author(s) and the source, provide a link to the Creative Commons license, and indicate if changes were made. 
been an increasing integration of Learning Technologies (LTs') into teaching and learning within the higher education sector (Laurillard, 2013). LTs' in this study is referred to software's' (word processing, spreadsheets, databases, PowerPoint, virtual learning), hardware (PCs, laptops, multi-media projectors, interactive whiteboard), as well as to internet applications (search engines, for example Google, Wikipedia, and social media sites such as Facebook, and Twitter).

There is a widespread belief that such technologies will transform teaching and learning practices, making them more significant, interesting and relevant to the students, and thereby radically changing the quality of learning students experience (Karasavvidis \& Kollias, 2014). Institutions in higher education are making a substantial investment in technologies to support teaching and learning (Bebell, Russell, \& O'Dwyer, 2004). The rapid advancement of learning technologies in higher education is attributed to the realisation that learning technologies can support, and innovate teaching (Fernández-Ferrer \& Cano, 2016) and enhance various forms of assessments (Farrell \& Rushby 2016). Drent and Meelissen (2008) argue that the deployment of learning technologies into the teaching and learning environment brings benefits for students, such that they are able to develop skills for searching and assessing information, collaboration, communication and problem solving. Research also shows that technologies can be used to improve the quality of teaching through the provision of professional development opportunities for teachers (Levin \& Wadmany, 2008; Mends-Brew, 2012; Peters, 2009; Ruhizan, Norazah, Mohd, Faizal, \& Jamil, 2014). Further, disruptive technologies such as Massive Open Online Courses (MOOCs) provide flexible online education for teachers, as well as opportunities for them to repurpose and adapt content to their own teaching (Conole, 2013; Kay, Reimann, Diebold \& Kummerfeld, 2013). Proponents of the use of technology in education suggest that technology will make education more accessible, more affordable, and more effective, whereas opponents of the use of technology in education claim that there is no significant difference in learning when technology is used in the education process (Abrahams, 2010).

Despite a growing enthusiasm in introducing these LTs' within the higher education environment, successful deployment and adoption is highly dependent on the provision of adequate resources (Pelgrum, 2001), and ability to address individual, contextual and cultural dynamics within a particular country. In addition, Karasavvidis and Kollias (2014) argue that the past three decades of research on technology use in teaching has failed to transform teaching and learning practices. The authors further stated two major reasons for the failure. First, there has been a low rate of technology usage in classrooms. Second, even though educators embrace technology, it gets integrated in ways which reinforces the status-quo rather than bringing innovation in teaching. Past research has also shown that institutional reforms led by technology have also failed (Zhao \& Frank, 2003). The connection between technology and learning can be seen as multifaceted phenomena, but research indicates that particular uses of technology can improve students' learning (Moeller \& Reitzes, 2011). Integration of technology into teaching allows faculty to accept individual differences in students' achievements, learning approaches and abilities, and at the same time providing students and faculty better flexibility in different learning modes (Massy \& Zemsky, 1995).

On individual level, educators are likely to face a number of challenges when adopting new technologies for the first time. These challenges often concern economic, 
technical, socio-political, attitudinal, and pedagogical issues (Shohel \& Kirkwood, 2012). Literature also mentions that, in order to effectively and efficiently embrace learning technologies, it is necessary to consider technical factors (Al-Senaidi, Lin, \& Poirot, 2009); teacher competencies (Samarawickrema \& Stacey, 2007), teachers' roles and pedagogical concerns (Kirkwood, 2015), organizational and financial support (Drent \& Meelissen, 2008), and safety and privacy concerns (Mitzner et al., 2010).

In order for successful integration of LTs, we need to better understand the factors that determine why some individuals adopt new technologies while others prefer to resist. The purpose of this study was to gain a better understanding of Fiji's Technical College lecturers' perceptions of the value of learning technologies and factors likely to influence their decisions to adopt and integrate these technologies into teaching. The research also aimed to identify educators' views on particular opportunities afforded by these technologies in enhancing student learning, as well as possible adoption challenges.

\section{Literature review}

Hall and Khan (2003) describe technology adoption as a consistent process that enables hesitant users to successfully adopt and use technology for a particular purpose. They pointed out that technology adoption occurs when users engage in a series of decisions that are outcomes of comparison of the advantages and disadvantages associated with the use of particular technologies. In the higher education sector, it is critical to understand the circumstances and conditions necessary for educators to embrace new technologies such as economic, socio-political, attitudinal, as well as pedagogical (Arenas, 2015; Shohel \& Kirkwood, 2012). Further, there is a general consensus in the literature suggesting that understanding technical issues, teacher competencies, teacher's role, pedagogical concerns, organisational and financial support, safety and privacy concerns are critical enablers of technology adoption (Alazam, Bakar, Hamzah, \& Asmiran, 2013; Bonsu, Duodu, JA, \& Djang-Fordjour, 2013; Buabeng-Andoh, 2012a; Peters, 2009). This body of research also stated that although technologies have the potential to make teaching and learning more interesting, it requires considerable input of teacher training, preparation and production of appropriate materials.

Alazam et al. (2013) identified a close relationship between having technology usage skills and level of technology integration in classroom. Similarly, other studies pointed out that better technology integration into the classroom is dependent on users' level of knowledge and technological skills (Buntat, 2010; Paryono \& Quito, 2010; Saud et al., 2010; Sukri, 2010). Further, Alazam et al. (2013) revealed that teachers' lack of technological skills was due to limited provision of pre-service and in-service training opportunities on the effective use of technology in the classroom.

In some studies, the lack of computers and access to them, lagging ICT infrastructural development, cost of training materials, and poor ICT competency skills are identified as significant barriers to technology adoption (Bonsu et al., 2013). Early research on uptake of ICT in Fiji pointed out that inadequate infrastructure, lack of awareness of the value of technologies poor skills, and cultural challenges were barriers to adoption (Lynch, Szorenyi, \& Lodhia, 2002). Similarly, Al-Senaidi, Lin and Poirot (2009) pointed out that the lack of equipment, institutional support, disbelief in ICT benefits, 
and lack of time, are some of the factors that cause barriers to technology integration. Shohel and Kirkwood (2012) pointed out that resistance to technology adoption can be attributed to risk perception and uncertainty, which can limit teachers' ability to make full evaluations of technology integration (Howard, 2013). Within some faculty, lack of time commitment contributed to poor integration of technology into teaching (Amanortsu, Dzandu, \& Asabere, 2014).

Analysis of various factors likely to influence educators' adoption of learning technology and the subsequent integration into teaching is critical. In this study we employ Decomposed Theory of Planned Behaviour (DTPB) as proposed by Taylor and Todd (1995b) to guide our analysis. According to Taylor and Todd (1995b), DTPB offers more transparency and clear relations among beliefs, attitudes and intentions. It can be applied to examine issues in a range of situations, offers a generic framework for identifying specific factors that lead to adoption and use of new technology. In the DTPB attitudinal beliefs are deconstructed into three concepts; namely, perceived usefulness, ease of use and compatibility (Taylor \& Todd, 1995a). Normative beliefs are also important constructs within the DTPB framework, and they are associated with difference between the opinions of key reference groups in an organisational setting (supervisors, colleagues, and friends). Moreover, control beliefs are broken down into two groups: self-efficacy and resource facilitating conditions. Self-efficacy relates to perceived ability of using a new technology. Facilitating conditions refers to the availability of time, money and technological resources for technology adoption. DTPB suggests that the clearer the perceptions of both self-efficacy in the new technology and the existing facilitating conditions, the more likely is the intention to adopt the innovation (Taylor \& Todd, 1995a).

\section{Fiji higher education system}

Fiji is a country made up of about 360 Islands in the Pacific Ocean. It is inhabited by an estimate of 895,825 people. Despite the presence of numerous Islands, the majority of the population ( $80 \%$ ) live in only two prominent Islands of Viti Levu and Vanua Levu. The Ministry of Education (MOE) is the responsible for the administration of the educational system. English is the official language of instruction in schools. The tertiary and the higher education sector is relatively small, with three universities: the University of the South Pacific, University of Fiji, and Fiji National University and a number of technical vocational education and training (TVET).

TVET has been in existence in Fiji from early 1950's with the aim of providing skills training for youths, as well as the working population wanting to attain higher skills and competencies. Until 2010 the structure of TVET in Fiji comprised three main organizations: school-based TVET under the Ministry of Education (MOE), the Fiji Institute of Technology (FIT), and non-formal training provided by the Training and Productivity Authority of Fiji (TPAF). However, TVET structure and curriculum programmes have undergone many changes in the last five years including the establishment of Fiji National University (FNU) in 2010. This came about as a result of a merger between six higher education institutions in Fiji, namely the Fiji Institute of Technology, Fiji School of Nursing, Fiji College of Advanced Education, Lautoka Teachers College, Fiji School of Medicine and Fiji College of Agriculture. In addition to 
FNU there are two more universities in Fiji called University of the South Pacific and University of Fiji.

Furthermore, as part of continued education reforms Fiji plans the closure of 71 TVET Centres attached to high schools within a two year period and establish 10 hitech technical colleges around the country by the year 2016 (Ministry of Education, 2014). There are three such colleges already established in early 2015 which are also chosen for this research. The Colleges offer qualifications under the newly established Fiji Qualifications framework with the aim to enhance skills based training for greater employment opportunity and economic growth (Ministry of Education, 2015). In the Ministry of Education Fiji vision for 'Quality Education for Change, Peace and Progress' that emphasises its role in delivering quality education for the betterment of the country and people in order to be globally competitive, it was stipulated that Fiji needs to develop highly skilled and knowledgeable workforce in order to compete in the globalised world.

In order to realise its vision, the Annual Business Plan 2015 saw a need to improve access to technology in education with the aim to improve teaching and learning through integration of technologies (Ministry of Education, 2015). This necessitates a need for educators in Fiji to embrace learning technologies in their daily teaching. While many of the new initiatives were mostly focused on primary, high schools and universities, not much evidence to show that polytechnic education also gets a similar preference. TVET lecturers' technology adoption and integration became an important initiative but remained unexplored. While, on the surface this seems an obvious way to align education within the national goal of progress and growth, the act of technology integration is fraught with challenges (Al-Senaidi et al., 2009; Alazam et al., 2013; Bonsu et al., 2013; Buabeng-Andoh 2012a, b; Drent \& Meelissen, 2008; Howard, 2013). The aim of this study was to explore Fiji's Technical Colleges lecturers' experiences and beliefs and values around the contribution of new learning technologies to enhance teaching and better student learning.

\section{Method and procedures}

Research reported in this article utilised a survey design. A questionnaire adapted from (Hartshorne \& Ajjan, 2009) was used a s a main instrument for gathering data about the types of technologies respondents have used, usage frequencies, value accrued to the use of technology, opportunities afforded by the integration of learning technologies into teaching as well as possible challenges. According to Teddlie and Tashakkori (2009), researchers employ questionnaire to gather selfreport data about attitudes, beliefs and feelings towards an issue of interest.

The survey instrument consisted of: technology adoption, nature of technology/ applications used, participants attitude towards technology use for teaching and learning, perceived ease of use, and usefulness of technology in teaching, current technology usage challenges, subjective norms, perceived behavioural control, selfefficacy, resources and support, intention of usage, and participants demographics. The instrument was tested for reliability and revealed a high Cronbach's Alpha $(\alpha=.832) ;(n=55)$. Results of the test indicated a good acceptability level considering that .70 is normally the cut-off value for being acceptable (Cortina, 1993). Formal approval for administrating the survey was obtained from the Research 
Unit of Fiji's Ministry of Education. Courtesy phone calls were made to the Director of the Technical College Fiji and the Senior Education officers informing about the study and also to seek their assistance in order to increase participation from the target population.

The survey was then made available online for the respondents in early August 2015. Data were collected within a two-week timeframe. There are only three Technical Colleges established this year with a total teaching staff population of 72 . However, questionnaire was only distributed to 63 staff members as some of the lecturers were away. A total of 55 respondents completed the survey. Sample Error: $5.5 \%$. In order to ascertain sample representativeness of sample from the population surveyed. Standard error of the sample was computed, revealing $(n=55$; $95 \%$ confidence, margin of error $5.5 \%)$.

\section{Data analysis and respondents' characteristics}

Data was analysed using Statistical Package for Social Science (SPSS) software. Descriptive statistics such as median, frequency, and percentage are used for analysis. Furthermore, factor analysis was also performed to identify key factors that are likely to influence adoption. The desired sample size was 63 but the actual number of respondents who took part in the study was 55 , yielding a high response rate of $76.3 \%$. Most of the respondents identified as male (37, 67\%), and reported a variety of academic positions, (44, $80 \%)$ lecturers and $(8,14 \%)$ heads of department in a variety of disciplines. Participant age range was normally distributed with the majority falling between the maximum of 31-40, (20,36.4\%); followed by those within the age range of 20-30, $(18,33 \%)$. Further, majority of respondents $(34,63 \%)$ rated their computer competence as intermediate; (15, $27.8 \%)$ mentioned advanced level knowledge and skills and only $(5,9.3 \%)$ were beginners. Competence in the use of technology can be attributed to a prior requirement to take pre-service computer related courses or to the lecturers' own effort to upgrade their technology handling skills.

\section{Factor analysis}

In order to determine factors likely to influence respondents' decisions in integrating technology into their teaching, principal axis factor analysis with varimax rotation was conducted to examine the underlying structure for 52 factors. A Kaiser-Meyer-Olkin (KMO) and principal component factor analysis were performed. The value of KMO was 0.7 , which suggests that the sample was adequate to proceed with principal component factor analysis. In addition, the value for Bartlett's test showed significance ( $p$ $<.000$ ) indicating high correlation among variables for factor analysis. The assumption of independent sampling, normality, linear relationship between pairs of variables, and variables being correlated at a moderate level were met. Furthermore, to examine construct validity, VARIMAX rotation was carried out with results (see Table 1). Table with rotated component Matrix is presented in Table 2. There were only 11 items whose loading values are $\geq 0.04$.

Fifty-one items loaded above accepted 0.60 threshold, which were then mapped to the items describing the decomposed theory of planned behavior. After rotation the first factor accounted for $35.3 \%$ of the variance (see Table 2). The items that loaded 
Table 1 Rotated Component Matrix

\begin{tabular}{|c|c|c|c|c|c|c|c|c|c|}
\hline \multirow[b]{2}{*}{ Item } & \multicolumn{9}{|c|}{ Component } \\
\hline & 1 & 2 & 3 & 4 & 5 & 6 & 78 & 9 & 1011 \\
\hline $\begin{array}{l}\text { I use computer technology hardware and software that } \\
\text { are designed to meet specific learning objectives }\end{array}$ & 0.8 & & & & & & & & \\
\hline Working with learning technologies is fun & 0.8 & & & & & & & & \\
\hline I use technology to facilitate students learning & 0.7 & & & & & & & & \\
\hline $\begin{array}{l}\text { I will recommend the idea of using technologies in } \\
\text { teaching to my colleagues }\end{array}$ & 0.7 & & & & & & & & \\
\hline I use technology to promote creativity & 0.7 & & & & & & & & \\
\hline $\begin{array}{l}\text { I use technologies into teaching to increase the } \\
\text { productivity of my lessons }\end{array}$ & 0.7 & & & & & & & & \\
\hline $\begin{array}{l}\text { Any learning technology makes work more interesting } \\
\text { for me }\end{array}$ & 0.6 & & & & & & & & \\
\hline I use computer technologies for exam preparations & 0.6 & & & & & & & & \\
\hline $\begin{array}{l}\text { I look forward to those aspects of teaching that involves } \\
\text { technologies }\end{array}$ & 0.6 & & & & 0.4 & & & & \\
\hline $\begin{array}{l}\text { I use computer technologies for exam analysis and } \\
\text { reports }\end{array}$ & 0.6 & & & & & & & & \\
\hline $\begin{array}{l}\text { I believe it is important for technical college lecturers to } \\
\text { use technologies in teaching }\end{array}$ & 0.6 & & -0.5 & & & & & & \\
\hline I am confident in using technologies in practical lessons & & 0.8 & & & & & & & \\
\hline $\begin{array}{l}\text { I am confident in using technologies in both theory and } \\
\text { practical lessons }\end{array}$ & & 0.8 & & & & & & & \\
\hline $\begin{array}{l}\text { I get enough time to incorporate technologies in } \\
\text { teaching }\end{array}$ & & 0.6 & & & & & & & \\
\hline $\begin{array}{l}\text { I am confident in my ability to use technologies in } \\
\text { practical lessons }\end{array}$ & & 0.6 & & & & & & & \\
\hline I am confident in using technologies in theory lessons & 0.4 & 0.6 & & & & & & & \\
\hline $\begin{array}{l}\text { My colleagues think I should use technologies in my } \\
\text { teaching }\end{array}$ & & 0.5 & & & & 0.4 & & & \\
\hline My peers/colleagues are using technologies in teaching & & 0.4 & & & & & & & \\
\hline $\begin{array}{l}\text { There is not enough institutional help for teachers to use } \\
\text { technologies for teaching }\end{array}$ & & & 0.9 & & & & & & \\
\hline $\begin{array}{l}\text { There are no incentives provided by my institution for } \\
\text { integrating technologies in teaching }\end{array}$ & & & 0.8 & & & & & & \\
\hline $\begin{array}{l}\text { Most teaching staff are not interested in using any forms } \\
\text { of technologies in their teaching }\end{array}$ & & & 0.8 & & & & & & \\
\hline I find use of technologies in teaching difficult & & & 0.7 & & & & & & \\
\hline $\begin{array}{l}\text { There are not enough computers and technologies } \\
\text { available for teaching in my institution }\end{array}$ & & & 0.7 & & & & & -0.5 & \\
\hline $\begin{array}{l}\text { Using technologies for teaching is entirely within my } \\
\text { control }\end{array}$ & & & & 0.8 & & & & & \\
\hline I would like to use technologies for teaching & & & & 0.7 & & & & & \\
\hline I have knowledge to use technologies in my teaching & & & & 0.7 & & & & & \\
\hline I have resources to use technologies in my teaching & & & & 0.7 & & & & 0.4 & \\
\hline $\begin{array}{l}\text { I would feel comfortable learning about new } \\
\text { technologies on my own }\end{array}$ & & & & 0.5 & & 0.4 & & & \\
\hline $\begin{array}{l}\text { I intend to learn and adopt more about technologies in } \\
\text { my teaching practices }\end{array}$ & & & & & 0.8 & & & & \\
\hline The advantages of using technologies in teaching & 0.4 & & & & 0.8 & & & & \\
\hline
\end{tabular}


Table 1 Rotated Component Matrix (Continued)

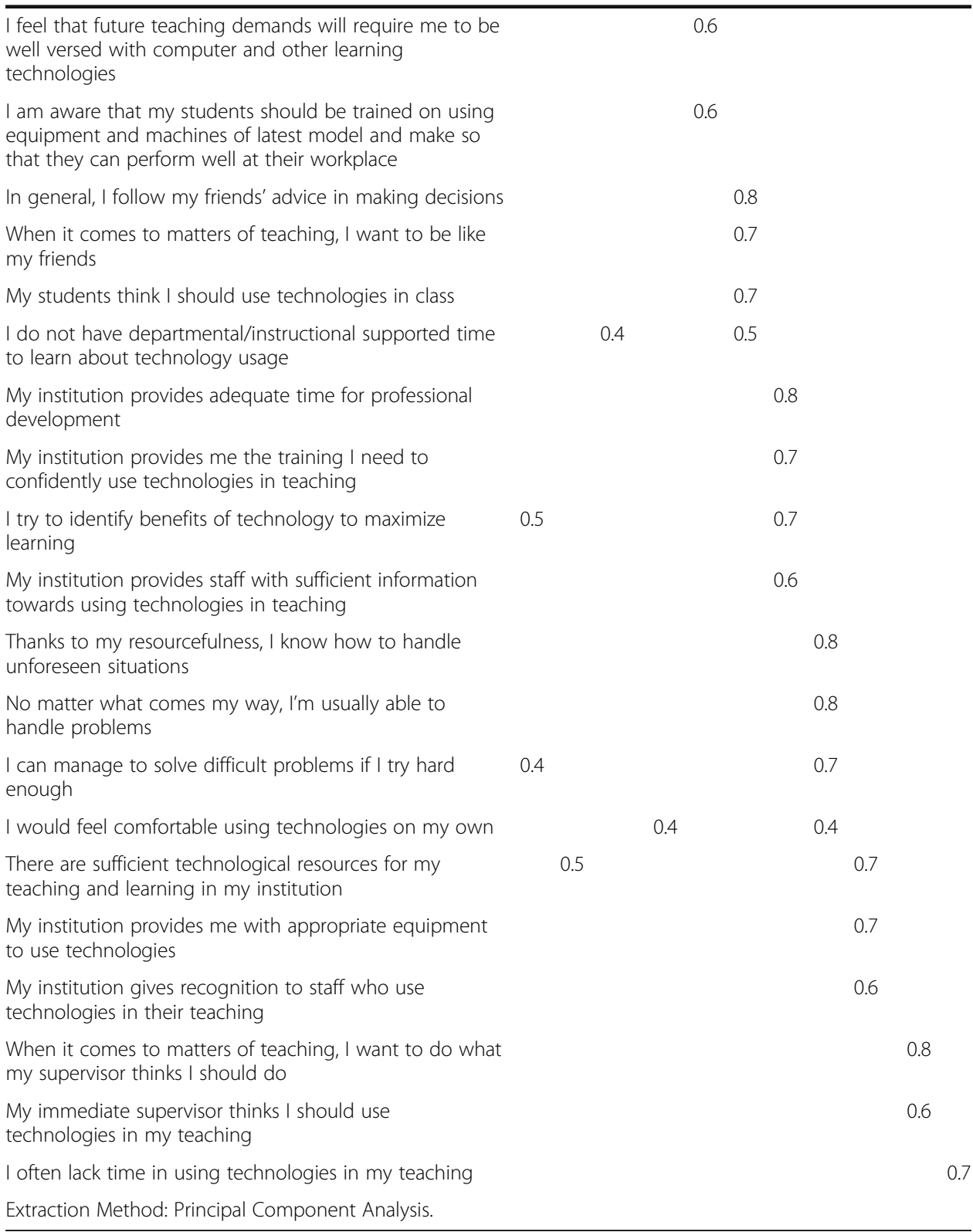

Rotation Method: Varimax with Kaiser Normalization

into this factor include attitudes towards technology and usefulness of technology in teaching. The second factor explained $9.7 \%$ of the variance. Items that loaded into this factor describe perceived ease of technology use. The third factor explained about $6.7 \%$ variance, describing technology usage challenges. The fourth factor explained $5.8 \%$ of the variance and was used to explain perceived behavior control. The fifth factor accounted for $4.5 .1 \%$ of the variance and was used to describe intention to use technology. The sixth factor which accounted for only $4.0 \%$ described subjected norms. The seventh factor described resources and support. The rest of the factors are presented in Table 1, each with an Eigenvalue $>1$. Further, items used to capture selfefficacy poorly loaded into the factors. 
Table 2 Total Variance Explained

\begin{tabular}{|c|c|c|c|c|c|c|c|c|c|}
\hline & Total & $\%$ of Var & Cum \% & Total & $\%$ of Var & Cum \% & Total & $\%$ of Var & Cum \% \\
\hline 1 & 16.5 & 34.3 & 34.3 & 16.5 & 34.3 & 34.3 & 6.8 & 14.1 & 14.1 \\
\hline 2 & 4.9 & 10.3 & 44.6 & 4.9 & 10.3 & 44.6 & 4.7 & 9.7 & 23.8 \\
\hline 3 & 3.2 & 6.6 & 51.2 & 3.2 & 6.6 & 51.2 & 4.0 & 8.2 & 32.0 \\
\hline 4 & 2.9 & 6.1 & 57.3 & 2.9 & 6.1 & 57.3 & 3.8 & 7.9 & 39.9 \\
\hline 5 & 2.1 & 4.4 & 61.6 & 2.1 & 4.4 & 61.6 & 3.6 & 7.6 & 47.5 \\
\hline 6 & 1.8 & 3.8 & 65.4 & 1.8 & 3.8 & 65.4 & 3.4 & 7.1 & 54.6 \\
\hline 7 & 1.7 & 3.6 & 69.0 & 1.7 & 3.6 & 69.0 & 3.2 & 6.6 & 61.2 \\
\hline 8 & 1.5 & 3.1 & 72.1 & 1.5 & 3.1 & 72.1 & 3.1 & 6.5 & 67.7 \\
\hline 9 & 1.3 & 2.8 & 74.9 & 1.3 & 2.8 & 74.9 & 2.1 & 4.3 & 72.0 \\
\hline 10 & 1.2 & 2.4 & 77.3 & 1.2 & 2.4 & 77.3 & 1.8 & 3.8 & 75.8 \\
\hline 11 & 1.0 & 2.2 & 79.5 & 1.0 & 2.2 & 79.5 & 1.8 & 3.7 & 79.5 \\
\hline 12 & 1.0 & 2.0 & 81.5 & & & & & & \\
\hline 13 & 0.9 & 1.9 & 83.4 & & & & & & \\
\hline 14 & 0.8 & 1.7 & 85.1 & & & & & & \\
\hline 15 & 0.8 & 1.6 & 86.7 & & & & & & \\
\hline 16 & 0.7 & 1.5 & 88.2 & & & & & & \\
\hline 17 & 0.7 & 1.4 & 89.7 & & & & & & \\
\hline 18 & 0.6 & 1.2 & 90.9 & & & & & & \\
\hline 19 & 0.5 & 1.1 & 91.9 & & & & & & \\
\hline 20 & 0.5 & 1.0 & 92.9 & & & & & & \\
\hline 21 & 0.4 & 0.9 & 93.8 & & & & & & \\
\hline 22 & 0.4 & 0.8 & 94.7 & & & & & & \\
\hline 23 & 0.4 & 0.7 & 95.4 & & & & & & \\
\hline 24 & 0.3 & 0.6 & 96.0 & & & & & & \\
\hline 25 & 0.3 & 0.6 & 96.6 & & & & & & \\
\hline 26 & 0.2 & 0.5 & 97.1 & & & & & & \\
\hline 27 & 0.2 & 0.4 & 97.6 & & & & & & \\
\hline 28 & 0.2 & 0.4 & 97.9 & & & & & & \\
\hline 29 & 0.2 & 0.4 & 98.3 & & & & & & \\
\hline 30 & 0.1 & 0.3 & 98.6 & & & & & & \\
\hline 31 & 0.1 & 0.3 & 98.8 & & & & & & \\
\hline 32 & 0.1 & 0.2 & 99.0 & & & & & & \\
\hline 33 & 0.1 & 0.2 & 99.2 & & & & & & \\
\hline 34 & 0.1 & 0.2 & 99.4 & & & & & & \\
\hline 35 & 0.1 & 0.2 & 99.5 & & & & & & \\
\hline 36 & 0.1 & 0.1 & 99.6 & & & & & & \\
\hline 37 & 0.0 & 0.1 & 99.7 & & & & & & \\
\hline 38 & 0.0 & 0.1 & 99.8 & & & & & & \\
\hline 39 & 0.0 & 0.1 & 99.9 & & & & & & \\
\hline 40 & 0.0 & 0.0 & 99.9 & & & & & & \\
\hline 41 & 0.0 & 0.0 & 99.9 & & & & & & \\
\hline 42 & 0.0 & 0.0 & 100.0 & & & & & & \\
\hline 43 & 0.0 & 0.0 & 100.0 & & & & & & \\
\hline 44 & 0.0 & 0.0 & 100.0 & & & & & & \\
\hline
\end{tabular}


Table 2 Total Variance Explained (Continued)

\begin{tabular}{llll}
\hline 45 & 0.0 & 0.0 & 100.0 \\
46 & 0.0 & 0.0 & 100.0 \\
47 & 0.0 & 0.0 & 100.0 \\
48 & 0.0 & 0.0 & 100.0 \\
\multicolumn{5}{l}{ Extraction Method: Principal Component Analysis. } \\
\hline
\end{tabular}

\section{Results}

\section{Utilisation of technology}

A large number of respondents indicated that they were generally competent in the use of available learning technologies (36, $67 \%$ ), and stated that they value the integration of technology into their teaching. Some stressed that their use of technology increased their creativity in teaching. In addition, (9, $16 \%)$ respondents reported using computers between two to three hours per day, while close to $(15,27 \%)$ respondents mentioned they spent between three to four hours per day. We asked respondents to indicate whether they had taken pre-service computer training. Three quarters of respondents $(41,75 \%)$ reported that they were required to take some form of formal computer training during their tertiary studies. It was also observed that (29, $53.7 \%)$ of participants did not participate in any formal technology training after joining the teaching profession. However, variations were observed in other institutions as nearly half of the respondents $(25,46.3 \%)$ indicated that they were required to undertake some computer related courses.

\section{Web usage}

Respondents were also asked about their engagement with resources on the web. Figure 1 shows that between the years 1992 to 19988 (15\%) respondents used the web for the first time.

However, between the years 2000 to 2009 the number increased by $61 \%$ (see Fig. 2). Furthermore, from 2005 there was an increased adoption of social network sites such as YouTube and Facebook. This could have been attributed to more lecturers using the web for research and teaching purposes. Results also showed that 47 (88.7 \%) lecturers fall in the combined intermediate and advance skills categories of web usage.

\section{Technology for teaching purpose}

As seen in Fig. 3 above, there seems to be a steady increase in the integration of technology into teaching from 2005 to 2009 representing 11 (20\%) respondents. From 2010 to 2015, there was a significant increase of $57 \%$, representing $55 \%$ of the total population who reported integrating technology into their teaching.

Respondents mentioned access to different forms of technologies which they either owned or were provided to them by their institutions, with an overall preference for laptops over iPads $(19,26 \%)$, which might be attributed to the fact that most of the institutions had only a few iPads available for the staff members compared to laptops. Nearly all respondents (51, $93 \%$ ) also reported proficiency in the use of office productivity software (e.g. Excel, Word, PowerPoint, etc.) 


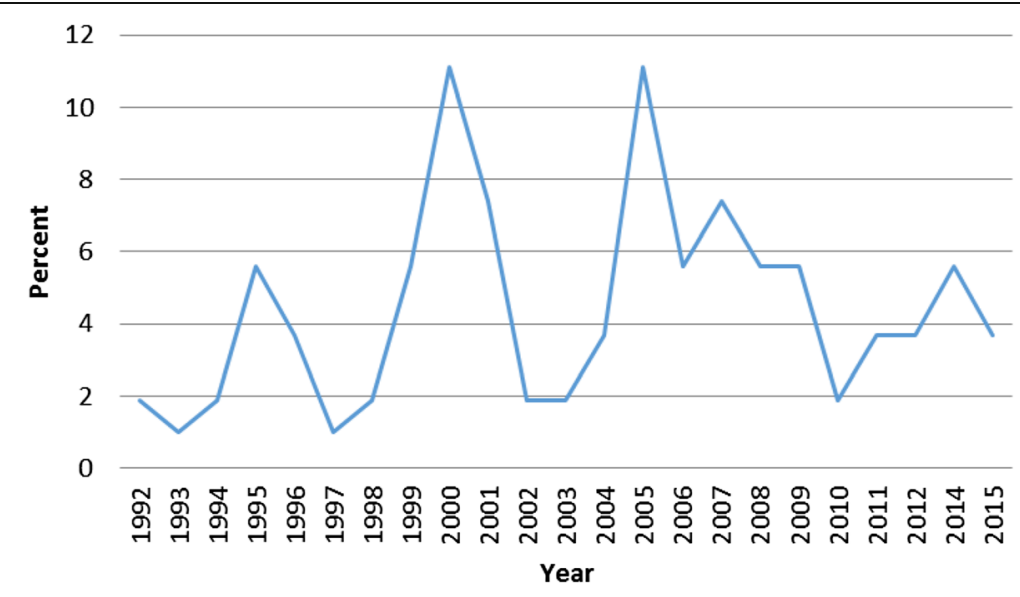

Fig. 1 First year of Web usage by respondents

\section{Social media}

Social media utilisation in teaching is an emerging area that has not been thoroughly investigated in the literature. In our analysis the vast majority of respondents (50, 93 \%) reported using YouTube, followed by Facebook (47, 87 \%). There was a shared view among respondents in support of the use of social media for teaching. It was believed that the current generation of students had wider exposure to many aspects of social media outside of class, therefore they could also use such media for their own learning. Furthermore, some respondents mentioned that

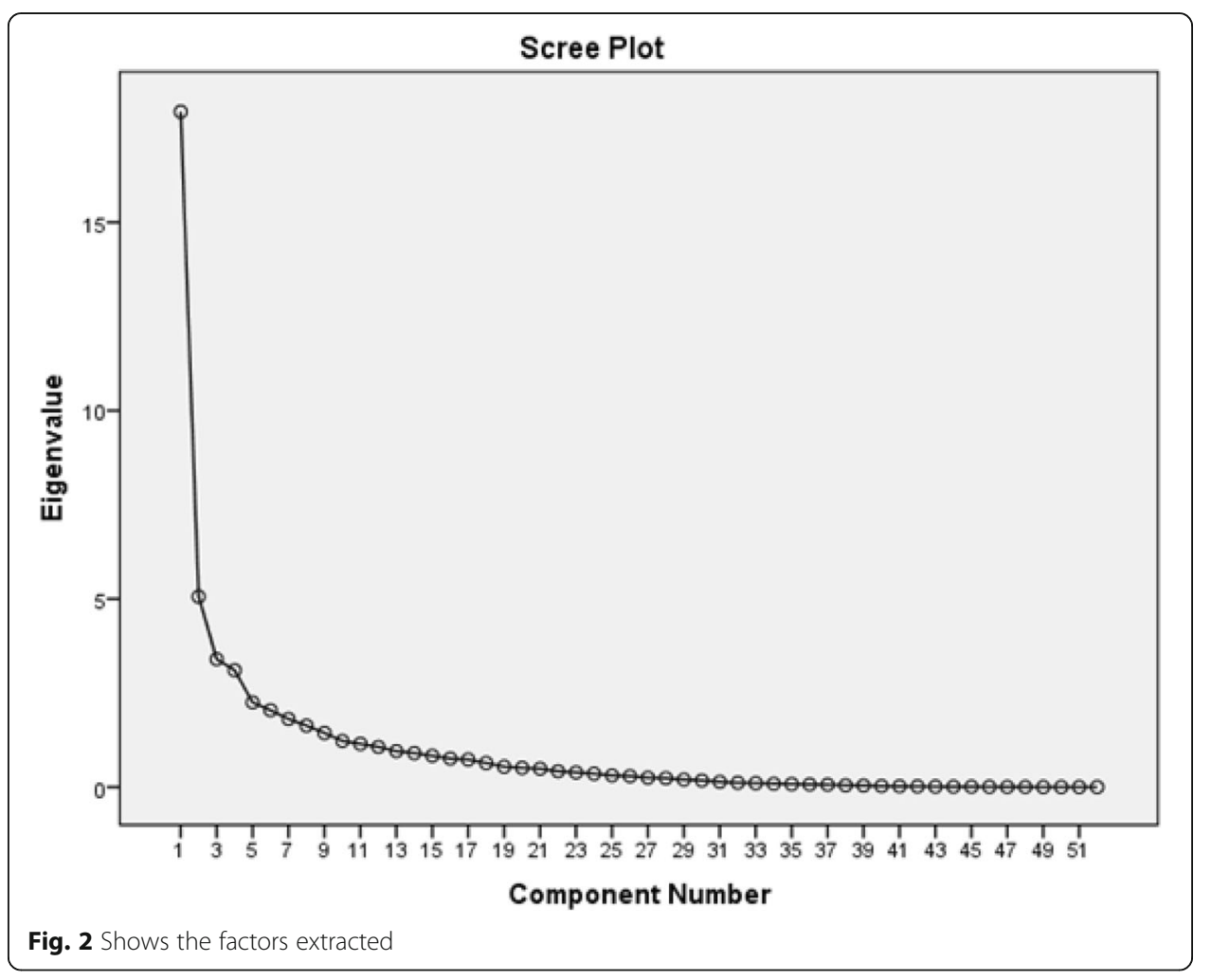




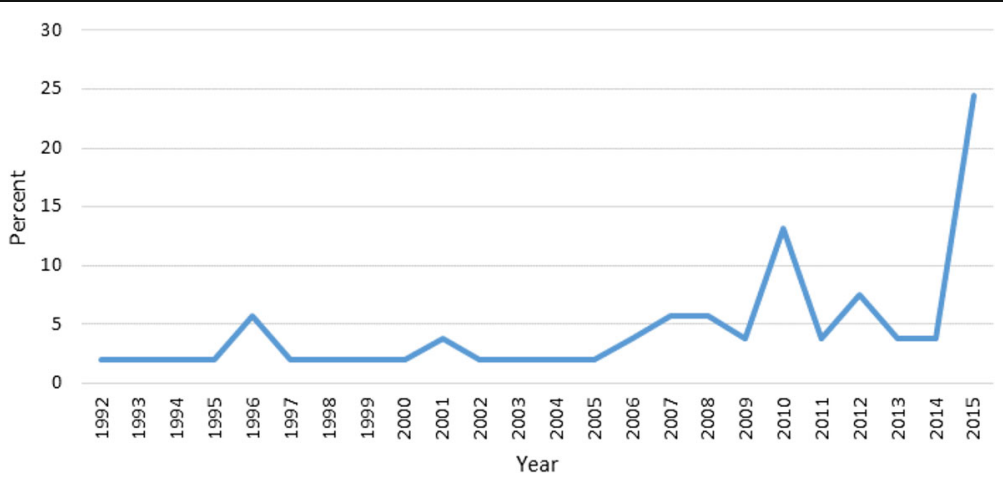

Fig. 3 Computers for teaching purpose

social media also allows them to share teaching and learning resources with their students and also with their colleagues.

\section{Factors likely to influence technology adoption}

Technology adoption in teaching is influenced by a number of factors. Some of the factors are associated with the environment, the nature of the technology, and personal attributes and preferences.

\section{Attitude towards technology adoption}

Almost all respondents reported that the use of technology makes their work easier (52, $94 \%)$. Some indicated that employing technology in teaching can help them effectively manage their time, especially during lecture preparation and presentation. A significant number (54, $98 \%$ ) mentioned that they have been using technologies in teaching and that the utilisation of technology for teaching helps engage students (53, $96 \%)$. In addition, (49, $88 \%)$ respondents mentioned they feel confident in integrating technology for various subjects. While (54, $98 \%)$ mentioned that they were likely to recommend the use of technology to their colleagues.

\section{Perceived ease of technology usage}

In line with the DTPB, Davis (1989) defines perceived ease of use as the degree to which a person believes that using a particular system would be effortless. Results from this study show $(35,60 \%)$ respondents agree that there is institutional support for technology adoption and that their technological ease of use is directly related to this institutional support.

Some respondents $(21,38 \%)$ mentioned time as a key factor likely to affect their ease of technology use in general. They also pointed out that the availability of appropriate resources plays an important role in determining the ease of technology use. Further, some respondents $(20,36.4 \%)$ stated that their technology use would depend on the availability of resources.

\section{Subjective norms}

DTPB suggests that subjective norms such as influence from peers and supervisors play can influence the degree to which people can embrace or reject integration of 
technology into their practices. The survey results indicated that majority of respondents $(52,96 \%)$ were aware their colleagues were using various forms of technologies in their teaching. They indicated that their colleagues are more likely to support their adoption of technology. In addition, majority of respondents mentioned their decision to integrate technology into teaching is likely to be influenced by their immediate supervisors' beliefs about the efficacy of technology in delivering better teaching outcomes. Additionally, almost three quarters $(41,74.6 \%)$ of respondents cited that they would follow what their supervisor thought was right for them. Similarly, almost (40, $73 \%)$ mentioned that possibility of integrating technology can also be influenced by views their students hold.

\section{Perceived behavioural control}

According to the DTPB perceived behavioural control refers to individuals' perceptions of their ability to accomplish a given behaviour and it is influenced by the availability of skills, resources, and opportunities that influence adoption of technologies in teaching. A large number of respondents $(48,87 \%)$ believed that the use of technology in teaching is within their control, and the availability of adequate resources and sufficient knowledge of technology significantly contributes to future adoption.

\section{Self-efficacy}

Self-efficacy is the belief in one's ability to successfully perform a technologically sophisticated new task. It does not focus on the skills one has, but rather the judgments of what one can do with his or her skills. In our analysis respondents (49, 89\%) demonstrated a great deal of self-efficacy, in that they can find solutions to problems if they try hard enough. Some pointed out that (52, $95 \%)$ they are more likely to handle unexpected situations with the current resources they have. In general respondents showed a high level of confidence in finding solutions to problems, and remaining confident solving complex problems involving technology in teaching. More than three quarters of $(48,87 \%)$ reported that they comfortably use existing technologies on their own.

\section{Resources and support}

Respondents were asked about the availability of resources and support in the use of technology in their institutions. More than half of the respondents 34 (62\%) believed they had adequate institutional support in possible integration of learning technologies into their teaching. In addition, (40, $73 \%$ ) believed that they were provided with adequate infrastructure. Furthermore, three quarters (41, $75 \%$ ) stated that their institutions recognise and likely to reward staff members who use technology in their teaching. They also mentioned that professional development was made available for them.

\section{Intention to use technology}

Intention to use technology is an aspect that captures the extent of willingness by individuals to use technological tools (Ajzen, 1991). The survey explore individuals' willingness to adopt technology in teaching. Results suggest that a vast majority (51, $93 \%$ ) agreed that they were aware of the future need and significance of integrating learning 
technologies into their teaching. They also mentioned that to train students using technology offers more advantages than disadvantages. As such many (54, $98 \%$ ) indicated they intend to continue with future integration of technology into their teaching. The survey also examined perceived challenges of integrating learning technology into teaching. Some (32, 58 \%) identified timed needed for better integration of learning technologies into teaching. Though some variation was observed across participating institutions as some respondents seemed to differ $(23,42 \%)$ that time is not an issue for them when integrating technology in their teaching.

\section{Discussion and conclusion}

The purpose of this study was to gain a better understanding of lecturers' perceptions of the value of learning technologies and factors likely to influence their decisions to adopt and integrate these technologies into teaching. The research also aimed to identify opportunities afforded by these technologies in enhancing student learning, as well as possible adoption challenges. Overall, results suggested that respondents strongly valued the contribution of learning technologies in enhancing student learning. Further, results revealed almost all respondents from the three technical colleges in Fiji were in the process of technology adoption. As mentioned earlier this research identified a number of factors likely to influence the rapid adoption of these technologies.

According to Pelgrum (2001), the success of any innovation is largely dependent on the skills and knowledge of the educators. Further, Buabeng-Andoh (2012b), mention that success of an educational technology programme in any institution depends on the teachers' support, and their attitudes as well as the beliefs they hold about the potentials of a particular technology in transforming their teaching practice, and enhancing student learning. Majority of respondents in this study believed that using learning technologies would significantly contribute to the efficacy of their teaching. More specifically, they stressed that integrating learning technologies into their teaching would offer a greater opportunity for student engagement, which confirms the views in the literature suggesting that educational technology provides prospects for students to develop their creativity and enhance reasoning skills, critical thinking skills, communication skills and other higher order thinking (Chigona \& Chigona, 2010; Trucano, 2005). Respondents who are already currently employing learning technologies in their teaching said they use them for creativity, to facilitate students' learning, to meet specific learning objectives, and to perform academic tasks.

Another key findings in this research is that lectures value the contribution of learning technologies to student learning. Research currently suggest that users attitude and perceived usefulness of technology are the key factors necessary in supporting the possible integration of learning technologies into teaching The observations reported here are consistent with outcomes of similar studies, noting that attitude was a key factor in determining technology adoption (Shiue, 2007; Teo, 2008, 2012; Taylor \& Todd, 1995). Further, attitude, behavioural controls, self-efficacy, perceived usefulness and intention to use technology are key factors identified, that are likely to influence future adoption and integration of learning technologies into teaching. In addition, related factors such as ease of use, knowledge, and confidence in handling technologies were also viewed important. Similar to previous work, analysis of the data revealed that majority of 
respondents believed that the use of technology in teaching was within their control, these results are in line with the literature (Ajzen \& Madden 1985).

An individual intention to experiment with new technologies in general is an important predictor for future adoption of technology. Further, Teo (2012) examined the intention to use technology among pre-service teachers and found that subjective norms have a significant influence on teachers' behavioural intentions to use technology. In the survey, respondents mentioned that they keen to integrate technologies into their teaching. Within the DPBT, peer and supervisory influence were additional important strong predictors of future adoption. Peer and supervisory influence as predictors of technology adoptions are both culturally bounded. In the case of Fiji, collective cultural practices and strong hierarchical power structures have direct influence on the extent of subjective, peer and supervisory factors for adoption of technologies (Lynch, Szorenyi, \& Lodhia, 2002; Schepers \& Wetzels, 2007; Venkatesh \& Davis, 2000). Further, institutional level factors such as resources, funding, incentives, supervisors' influence, and technology related professional opportunities were also identified as critical.

Generally, respondents were fully aware of the opportunities afforded by learning technologies and expressed their willingness to adopt and integrate these technologies into their teaching. Respondents also acknowledge the challenges likely to interfere with future adoptions, and stressed the role of institutions to overcome systemic barriers to adoption. On the other hand, Mumtaz (2000) noted that institutions can only go so far in providing up-to-date technology, related support, and encouragement for technology usage but the actual take-up depends largely on individuals' personal feelings, skills and attitudes.

The results of this study showed that respondents have a high level of self-efficacy, which is likely to help them overcome issues they might face during technology integration. However, as new technologies continue to permeate the higher education landscape, for effective integration there will be a need for many lecturers to familiarise themselves with various technologies, to develop confidence. Respondents reported possible barriers to effective integration of learning technologies into teaching include a lack of knowledge and skills, inadequate resource and support from administrators and the institutions, and the sociocultural dynamics within the Fijian context. This particular finding is consistent with Lynch, Szorenyi and Lodhia (2002) analysis of cultural differences and how this would likley influence technology adotpion. This research contributes to the growing significance of individual, contextual and cultural influences in the adoption of learning technologies into teaching.

\section{Study limitations}

Even though this research has contributed to contextual and institutional factors likely to influence the integration of learning technologies into teaching in Fiji, it was conducted in technical colleges, results of which might not apply in other higher institutions in Fiji. Moreover, the sample was self-selected and might already be influenced by social desirability bias in that only those interested in the use of technology in teaching might have contributed. Future research need to deploy a systematic observation, including focus group and critical analysis of institutional documents such as curriculum plans, and technology inventory records. Furthermore, results would have been more meaningful and richer if students and administrators were also involved in the study. 


\section{Acknowledgement}

The research reported in this article was part of a Master's thesis funded by NZAid. The researchers would like to acknowledge scholarship support from NZ for Shalendra Kumar, and postgraduate writing grant from the department of Higher Education, at the University of Otago, New Zealand.

\section{Authors' contribution}

Both authors contributed equally towards this article.

\section{Authors' information}

Mr. Shalendra Kumar is the head of department and the acting principal of a Fiji Higher Education Commission (FHEC) registered TVET institute. He is also a registered accessor and evaluator of TVET programs with FHEC. His research interest is looking at ways to enhance the teaching and learning of TVET in Fiji, particularly focusing on on use of learning technologies by lecturers. Dr. Ben Kei Daniel is a Senior Lecturer in Educational Technology and Research Methodologies, in Higher Education. He currently leads an Educational Technology Group, at the University of Otago-New Zealand. His research is focused on understanding the value of Big Data and learning analytics in highereducation. He is also investigating theories and praxis of teaching Research Methodologies for Academia and Business.

Received: 9 June 2016 Accepted: 6 September 2016

Published online: 08 November 2016

\section{References}

Abrahams, D. A. (2010). Technology adoption in higher education: a framework for identifying and prioritising issues and barriers to adoption of instructional technology. Journal of Applied Research in Higher Education, 2(2), 34-49.

Ajzen, I., \& Madden, T. (1985). From intentions to action: a theory of planned behaviour. In J. Kuhl \& J. Beckmann (Eds.), Action control: from cognition to behaviour. New York: Springer Verlag.

Ajzen, I. (1991). The theory of planned behavior. Organizational behavior and human decision processes, 50(2), 179-211.

Alazam, A.-O., Bakar, A., Hamzah, R., \& Asmiran, S. (2013). Teachers' ICT skills and ICT integration in the classroom: the case of vocational and technical teachers in Malaysia. Creative Education, 3(8), 70-76.

Al-Senaidi, S., Lin, L., \& Poirot, J. (2009). Barriers to adopting technology for teaching and learning in Oman. Computers \& Education, 53(3), 575-590.

Amanortsu, G., Dzandu, M. D., \& Asabere, N. Y. (2014). Towards the access to and usage of information and communication technology (ICT) in polytechnic education. International Journal of Computer Applications, 66(1), 23-33.

Arabasz, P., \& Baker, M. B. (2003). Evolving campus support models for e-learning courses. Educause Center for Applied Research Bulletin, 1-9. Retrieved 10 September 2016 from: http://net.educause.edu/ir/library/pdf/ers0303/ekf0303.pdf.

Arenas, E. (2015). Affordances of learning technologies in higher education multicultural environments. Electronic Journal of E-Learning, 13(4), 217-227. Retrieved from http://0-search.proquest.com.cataleg.uoc.edu/docview/ 1697674722 ?accountid $=15299$.

Bebell, D., Russell, M., \& O'Dwyer, L. (2004). Measuring teachers' technology uses: Why multiple-measures are more revealing. Journal of Research on Technology in Education, 37(1), 45-63.

Bonsu, K., Duodu, A., JA, A., Bonsu, K., Duodu, A., Ansere, J. A., \& Djang-Fordjour, K. (2013). The challenges and prospects of ICTs in teaching and learning in sunyani polytechnic, Ghana. Capa Scientific Journal, 1(1), 12-17.

Buabeng-Andoh, C. (2012a). Factors influencing teachers' adoption and integration of information and communication technology into teaching: A review of the literature. International Journal of Education and Development using Information and Communication Technology, 8(1), 136.

Buabeng-Andoh, C. (2012b). Factors influencing teachers' adoption and integration of information and communication technology into teaching: A review of the literature. International Journal of Education and Development using Information and Communication Technology, 8(1), 136-155.

Buntat, Y. (2010). Computer technology application and vocational education: a review of literature and research. European Journal of Social Sciences, 14(4), 645-651.

Business Plan 2015 Ministry of Education, Heritage and Arts: Retrieved 15 September 2016 from http://www.education. gov.fj/images/AnnualBusinessPlans/2015_ABP.pdf.

Chigona, A., Chigona, W., Kayongo, P., \& Kausa, M. (2010). An empirical survey on domestication of ICT in schools in disadvantaged communities in South Africa Agnes Chigona, Wallace Chigona, Patrick Kayongo and Moses Kausa University of Cape Town, South Africa. International Journal of Education and Development using Information and Communication Technology, 6(2), 21-32.

Conole, G. (2013). MOOCs as disruptive technologies: strategies for enhancing the learner experience and quality of MOOCs. RED. Revista de Educación a Distancia, (39), 1-17. Retrieved 10 September 2016, from http://revistas.um.es/ red/article/view/234221/179941.

Cortina, J. M. (1993). What is coefficient alpha? an examination of theory and applications. Journal of Applied Psychology, 78(1), 98.

Davis, F. D. (1989). Perceived Usefulness, Perceived Ease Of Use, And User Accep. MIS Quarterly, 13(3), 319.

Drent, M., \& Meelissen, M. (2008). Which factors obstruct or stimulate teacher educators to use ICT innovatively? Computers \& Education, 51(1), 187-199.

Farrell, T., \& Rushby, N. (2016; 2015). Assessment and learning technologies: An overview. British Journal of Educational Technology, 47(1), 106-120. doi:10.1111/bjet.12348

Fernández-Ferrer, M. \& Cano, E. (2016). The influence of the internet for pedagogical innovation: using twitter to promote online collaborative learning. International Journal of Educational Technology in Higher Education, 13(22). doi:10.1186/s41239-016-0021-2

Hall, B. H., \& Khan, B. (2003). Adoption of new technology (No. w9730). National Bureau of Economic Research. Retrieved on 10 September 2016 from: http://www.nber.org/papers/w9730.

Hartshorne, R., \& Ajjan, H. (2009). Examining student decisions to adopt Web 2.0 technologies: theory and empirical tests. Journal of Computing in Higher Education, 21(3), 183-198. 
Howard, S. K. (2013). Risk-aversion: understanding teachers' resistance to technology integration. Technology, Pedagogy and Education, 22(3), 357-372.

Karasavvidis, I., \& Kollias, V. (2014). Technology integration in the most favorable conditions: findings from a professional development training program. In C. Karagiannidis (Ed.), Research on e-learning and ICT in education (pp. 197-224). New York: Springer.

Kay, J., Reimann, P., Diebold, E., \& Kummerfeld, B. (2013). MOOCs: So many learners, so much potential. Technology, 52(1), 49-67.

Kirkwood, A. (2015). Teaching and learning with technology in higher education: blended and distance education needs 'joined-up thinking'rather than technological determinism. Open Learning: The Journal of Open, Distance and e-Learning, 29(3), 1-16.

Laurillard, D. (2013). Teaching as a Design Science: Building Pedagogical Patterns for Learning and Technology. New York: Routledge, Taylor \& Francis Group.

Levin, T., \& Wadmany, R. (2008). Teachers' views on factors affecting effective integration of information technology in the classroom: developmental scenery. Journal of Technology and Teacher Education, 16(2), 233-263.

Lynch, T., Szorenyi, N., \& Lodhia, S. (2002). Adoption of information technologies in Fiji: issues in the study of cultural influences on information technology acceptance. Paper presented at the ITIRA conference. Rockhampton: Central Queensland University.

Massy, W. F., \& Zemsky, R. (1995). Using information technology to enhance academic productivity. Washington, DC: InterUniversity Communications Council, Inc.

Mends-Brew, E. (2012). Enhancement of ICT in polytechnics for accelerated development. Natural and Applied Science, 3(3), 99-107.

Ministry of Education, H. a. A. (2014). Annual Corporate Plan. Government of Fiji reports: Available at: http://www. education.gov.fj/index.php/resources/photo-movies.

Ministry of Education, H. a. A. (2015). Annual Corporate Plan. Government of Fiji reports: Available at: http://www. education.gov.fj/index.php/resources/photo-movies.

Mitzner, T. L., Boron, J. B., Fausset, C. B., Adams, A. E., Charness, N., Czaja, S. J., \& Sharit, J. (2010). Older adults talk technology: technology usage and attitudes. Computers in Human Behavior, 26(6), 1710-1721.

Moeller, B., \& Reitzes, T. (2011). Integrating technology with student-centered learning. A report to the Nellie Mae education foundation. Retrieved from http://www.nmefoundation.org/getmedia/befa9751-d8ad-47e9-949d-bd649f7c0044/integrating.

Mumtaz, S. (2000). Factors affecting teachers' use of information and communications technology: a review of the literature. Journal of Information Technology for Teacher Education, 9(3), 319-342.

Paryono, \& Quito, B. G. (2010). Meta-analysis of ICT integration in vocational and technical education in southeast asia. In An International Conference on VTET Research and Networking. SEAVERN Research Report. SEAMO VOCTECH Regional Centre, Brunei Darussalam. From: http://www.voctech.org.bn/conference/papers/ [VOCTECH]\%20Paryono\%20\&\%20Ben.pdf.

Pelgrum, W. J. (2001). Obstacles to the integration of ICT in education: results from a worldwide educational assessment. Computers \& education, 37(2), 163-178.

Peters, L. (2009). Global education: using technology to bring the world to your students. Washington, DC: International Society for Technology in Education.

Ruhizan, M., Norazah, M., Mohd, B. R., Faizal, A., \& Jamil, A. (2014). Vocational education readiness in Malaysia on the use of e-portfolios. Journal of Technical Education and Training, 6(2), 157-171.

Samarawickrema, G., \& Stacey, E. (2007). Adopting Web-based learning and teaching: a case study in higher education. Distance Education, 28(3), 313-333.

Saud, MS., Rajuddin, B., Ismail, S., Nordin, MS., Minghat, AD., Subari, K., \& Arsat, M. (2010). ICT application in vocational and technical education and training (VTET) institutions in Malaysia. SEAVERN journals, 2(1). Retrieved 15 September, 2016 from http://s3.amazonaws.com/academia.edu.documents/25676036/64-35-1-SM.pdf?AWSAccessKeyld= AKIAJ56TQJRTWSMTNPEA\&Expires=1473889551\&Signature=y7DVe\%2FjbIPRJmefpdwW4ID790Fg\%3D\&responsecontent-disposition=inline\%3B\%20filename\%3DICT_Application_in_Vocational_and_Techni.pdf.

Schepers, J., \& Wetzels, M. (2007). A meta-analysis of the technology acceptance model: Investigating subjective norm and moderation effects. Information \& Management, 44(1), 90-103.

Shiue, Y.-M. (2007). Investigating the sources of teachers' instructional technology use through the decomposed theory of planned behavior. Journal of Educational Computing Research, 36(4), 425-453.

Shohel, M. M. C., \& Kirkwood, A. (2012). Using technology for enhancing teaching and learning in Bangladesh: challenges and consequences. Learning, Media and Technology, 37(4), 414-428.

Sife, A., Lwoga, E., \& Sanga, C. (2007). New technologies for teaching and learning: Challenges for higher learning institutions in developing countries. International Journal of Education and Development using ICT, 3(2), 57-67.

Sukri, M. (2010). ICT application in vocational and technical education and training (VTET) institutions in Malaysia. Paper presented at the An International Conference on VTET Research and Networking. SEAVERN Research Report. SEAMO VOCTECH Regional Centre, Brunei Darussalam. Retrieved from http://www.voctech.org.bn/conference/ papers/[MY]\% 20Dr.\% 20Sukri\% 20Saud\% 20\&\% 20Prof.\% 20Rashid. pdf.

Taylor, S., \& Todd, P. (1995). Decomposition and crossover effects in the theory of planned behavior: a study of consumer adoption intentions. International Journal of Research in Marketing, 12(2), 137-155.

Teddlie, C., \& Tashakkori, A. (Eds.). (2009). Foundations of mixed methods research: Integrating quantitative and qualitative approaches in the social and behavioral sciences. Sage Publications Inc

Teo, T. (2008). Pre-service teachers' attitudes towards computer use: a Singapore survey. Australasian Journal of Educational Technology, 24(4), 413-424

Teo, T. (2012). Examining the intention to use technology among pre-service teachers: an integration of the technology acceptance model and theory of planned behavior. Interactive Learning Environments, 20(1), 3-18.

Trucano, M. (2005). Knowledge maps: ICTs in education. Washington, DC: InfoDev/World Bank.

Venkatesh, V., \& Davis, F. D. (2000). A theoretical extension of the technology acceptance model: four longitudinal field studies. Management Science, 46(2), 186-204.

Zhao, Y., \& Frank, K. A. (2003). Factors affecting technology uses in schools: an ecological perspective. American Educational Research Journal, 40(4), 807-840. 